\title{
O TRABALHo Universitário: A EXPERIÊNCIA PORTUGUESA
}

\section{The University Work: The Portuguese EXPERIENCE}

\section{El Trabajo De La Universidad: La ExPERIENCIA PORTUGUESA}

João Carlos Relvão Caetano

1 Introdução. 2 Dimensões analíticas do problema. 3 De como o papel das universidades está a mudar. 4 Preparemo-nos para os fogos que inevitavelmente virão. 5 Para onde os universitários portugueses querem ir e para onde vão efetivamente. 6 Conclusões. Referências.

\section{RESUMO}

No presente artigo, faz-se uma análise do trabalho dos universitários portugueses no séc. XXI, partindo-se do que estabelece a lei. Analisa-se concretamente o artigo $4^{\circ}$ do Estatuto da Carreira Docente Universitária (ECDU), que estabelece as funções dos docentes universitários (investigação, docência, transferência do conhecimento e gestão). Procura saber-se o que é o trabalho universitário, quem são os trabalhadores universitários portugueses e de que modo se comportam e por quê. Embora se parta da lei, a perspetiva teórica é interdisciplinar, apoiando-se em abundantes factos. Mostra-se a evolução do sistema universitário português nas últimas décadas e os reflexos que tem no desempenho dos agentes. Evidencia-se a complexidade das tarefas dos universitários portugueses nos inícios do novo século, as dificuldades de carreira e os desafios que têm pela frente. Mostra-se a significativa relevância do seu trabalho para o desenvolvimento da sociedade. Reflete-se ainda sobre o reconhecimento que a lei, o Estado e a sociedade devem ter sobre o seu trabalho.

Palavras-chave: Trabalho dos universitários. Direito. Estado. Sociedade. Desenvolvimento.

* Doutor em Ciências Políticas. Professor Auxiliar no Departamento de Ciências Sociais e de Gestão (DCSG) da Universidade Aberta (UAb).Universidade Aberta, Portugal.E-mail: <Joao.Caetano@uab.pt>.https:// orcid.org/0000-0002-2833-5107 


\begin{abstract}
In this article, the author makes an analysis of the work of Portuguese teachers and researchers in the $21^{\text {st }}$ century, starting from what is stablished by the positive law. The author concretely analyses the contents of Article 4 of the Statute of the University Teaching Career (ECDU), which defines the functions of university teachers (research, teaching, transfer of knowledge and management), seeks to know what university work is, who the Portuguese university workers are and how they behave and why. Although based on the law, the theoretical perspective is interdisciplinary, relying on abundant facts. The author shows the evolution of the Portuguese university system in recent decades and the repercussions it has on the performance of its agents. He also highlights the complexity of the tasks of the Portuguese university teachers and researchers at the beginning of the new century, the difficulties of the career and the challenges that lie ahead. The author shows the significant relevance of the agents' work to the development of society. Finally, he also reflects on the recognition that law, state and society should have on the agents' work.
\end{abstract}

Keywords: University Work. Law. State. Society. Development.

\title{
RESUMEN
}

En este artículo, el autor hace un trabajo de análisis de la universidad portuguesa en el siglo XXI, partiendo de lo que establece la ley. Se analiza concretamente el artículo 4 del Estatuto de la Carrera Docente Universitaria (ECDU), que establece las funciones de los docentes universitarios (investigación, docencia, transferencia del conocimiento y gestión). Se busca saber lo que es el trabajo universitario, quienes son los trabajadores de la universidad portuguesa y cómo se comportan y por qué. Aunque se parta de la ley, la perspectiva teórica es interdisciplinaria, apoyándose en abundantes hechos. Se muestra la evolución del sistema universitario portugués en las últimas décadas y las consecuencias que tiene sobre el desempeño de los agentes. Se evidencia la complejidad de las tareas de los universitarios portugueses a principios del nuevo siglo, sus dificultades de carrera y los desafíos que tienen por delante. Se muestra la significativa relevancia del trabajo de los agentes para el desarrollo de la sociedad. Se reflexiona, por fin, acerca del reconocimiento que la ley, el Estado y la sociedad deben tener sobre el trabajo universitario.

Palabras clave: Trabajo de los Universitarios. Derecho. Estado. Sociedad. Desarrollo.

\section{INTRODUÇÃO}

No presente artigo, faço uma reflexão sobre o significado do trabalho universitário no contexto da sociedade portuguesa, como sociedade capitalista avançada, nos inícios do século XXI. 
Por trabalho universitário, refiro-me ao trabalho dos professores e dos investigadores ${ }^{1}$ exercido no âmbito de instituições, como as próprias universidades, os institutos de investigação universitários ou as outras entidades, públicas e privadas. Não me refiro ao trabalho dos outros agentes integrantes dos processos universitários, por exemplo, o pessoal administrativo e os técnicos especializados, porque o seu trabalho, apesar de poder ser muito relevante, é de apoio às tarefas dos professores e dos investigadores.

A relevância deste trabalho se prende ainda ao facto de a atividade universitária estar hoje no centro das políticas públicas em Portugal e mudar significativamente. A questão é paradoxal porque se, por um lado, se verifica um subfinanciamento do setor da ciência, tecnologia e ensino superior, em virtude das políticas de austeridade levadas a cabo por sucessivos governos, por outro lado, entende-se que as universidades produzem bens transacionáveis e, por isso, são muito relevantes para a economia do país. Também a produção e a disseminação do conhecimento é vista como essencial para reforçar a competitividade das empresas e aumentar o emprego.

Por essas razões, já no séc. XXI, houve importantes passos legislativos visando à transformação das universidades em Portugal, com reflexos na vida dos universitários.

No presente artigo, faço uma análise dessa evolução e dos desafios que levanta para os universitários portugueses. Começo por analisar o significado do artigo $4^{\circ}$ do Estatuto da Carreira Docente Universitária (ECDU), que define as funções dos docentes universitários, para posteriormente caracterizar o trabalho destes em Portugal. Procuro ainda definir o contexto de desenvolvimento das políticas públicas na área, o que decorre fundamentalmente de fatores externos, tanto europeus como globais.

Procuro ainda antecipar, em termos gerais, o que será o trabalho dos universitários portugueses no futuro. Será um trabalho como todos os outros ou terá especificidades? Por entender que as universidades desempenham uma função de soberania, dada a relevância da qualidade da formação das pessoas para a própria afirmação e o desenvolvimento da coletividade política, considero que o trabalho universitário deve ser visto com especial atenção. Os universitários devem poder constituir-se como uma elite democrática e solidária ao serviço do progresso da comunidade política, o que implica que o seu trabalho deve ser política e socialmente reconhecido e valorizado, contrariando, desse modo, uma tendência dos últimos anos.

Deve-se assinalar ainda que a temática do trabalho universitário precisa passar as fronteiras da discussão sindical e político-parlamentar para ser objeto de discussão no espaço público, como matéria essencial à salvaguarda da democracia pluralista no séc. XXI. Se este artigo servir para cumprir esse propósito, cumprirá a sua missão, até pela circunstância de ser publicado no Brasil, um país com as mesmas tradições políticas e jurídico-administrativas, cujos académicos mantêm estreitas relações com os académicos portugueses.

1 Na tradição académica portuguesa, usam-se indistintamente as expressões investigação e pesquisa, assim como as palavras investigadores e pesquisadores. Todavia, a lei fala normalmente de investigação e de investigadores. 


\section{DIMENSÕES ANALÍTICAS DO PROBLEMA}

A lei portuguesa é clara ao tipificar o trabalho dos universitários em quatro funções: investigação, docência, transferência do conhecimento e gestão (artigo $4^{\circ}$ do Estatuto da Carreira Docente Universitária - ECDU). ${ }^{2}$

(Funções dos docentes universitários)

Cumpre, em geral, aos docentes universitários:

a) Realizar atividades de investigação científica, de criação cultural ou de desenvolvimento tecnológico;

b) Prestar o serviço docente que lhes for distribuído e acompanhar e orientar os estudantes;

c) Participar em tarefas de extensão universitária, de divulgação científica e de valorização económica e social do conhecimento;

d) Participar na gestão das respetivas instituições universitárias;

e) Participar em outras tarefas distribuídas pelos órgãos de gestão competentes e que se incluam no âmbito da atividade de docente universitário (PORTUGAL, 1979 , on-line). ${ }^{3}$

A lei equipara as quatro funções, não as hierarquizando ou priorizando. Prova disso é a crescente importância dada pelas universidades a atividades no âmbito da transferência do conhecimento ${ }^{4}$ e da gestão, com reflexos nos regulamentos de avaliação do desempenho dos docentes e nos concursos de progressão na carreira.

Por outro lado, diminuiu, nos últimos anos, por vontade tanto do poder político como dos reitores das universidades, o número daqueles que são exclusivamente investigadores. Em 2018, o reitor da Universidade de Lisboa, António Cruz Serra, em um artigo no jornal Público (SERRA, 2018), defendeu a conveniência de a lei vir a consagrar uma só carreira universitária, pondo-se termo à carreira de investigação. Não se trata de dar menos importância à investigação, mas de dar mais importância ao ensino e às demais funções, em articulação com a investigação.

2 Decreto-Lei n. ${ }^{\circ}$ 448/79, de 13 de novembro, alterado por sucessivas leis e decretos-leis até a presente década.

3 Esta quinta alínea tem caráter residual, não consubstanciando, na sistemática legal, uma quinta função dos docentes universitários.

4 Sinal de evolução, a transferência do conhecimento corresponde ao que até há poucos anos se chamava extensão universitária. É certo que o decreto-lei n. ${ }^{\circ}$ 448/79 continua a falar de extensão universitária, que é um conceito bem compreendido pelos agentes. Trata-se, porém, de um diploma antigo, que está desfasado com a linguagem atual, tanto dos documentos legais e de política legislativa como dos instrumentos internos das instituições de ensino superior. De notar ainda que o decreto-lei, apesar da sua vetusta idade, se refere à extensão universitária em articulação com a valorização económica e social do conhecimento, só que a realidade, entretanto, evoluiu muito. Com o advento do novo século, a transferência do conhecimento, normalmente associada à inovação, passou a ser um pelouro habitual nas equipes reitorais, assim como uma constante nos regulamentos internos de avaliação do desempenho dos docentes, dada a sua importância para a afirmação das instituições de ensino superior. Para uma análise aprofundada, veja-se: Pinto (2012). Como se explicará adiante, esta transformação decorre da crescente adoção pelas instituições de ensino superior portuguesas de objetivos de mercado. 
Esses desenvolvimentos reforçam a interpretação atualista que faço da lei portuguesa em vigor, no sentido de que as quatro funções são igualmente relevantes, sem prejuízo de poder haver percursos profissionais diferenciados, como, de facto, há. Por exemplo, pode justificar-se que uma pessoa, em um determinado período da sua vida profissional, se dedique exclusiva ou predominantemente à investigação ou à atividades de gestão, sem que, por isso, deva ser prejudicada na sua carreira.

Noto, porém, que esta é uma matéria ainda não suficientemente discutida nos meios jurídicos e académicos portugueses, razão pela qual este artigo também pode ser importante. A minha interpretação apoia-se no que diz a lei portuguesa e no que são as necessidades das instituições de ensino superior e investigação, portuguesas e de todo o mundo, no séc. XXI, desde logo, a necessidade de terem uma elevada produtividade que lhes garanta capacidade competitiva internacional.

É crucial que o desempenho dos docentes, na multiplicidade das suas funções, se reflita no desempenho das instituições como um todo. Em Portugal, à semelhança do que se passa em outros países, tanto os docentes como as instituições de ciência e ensino superior são avaliados, por exigências de qualidade. A agência de apoio à investigação científica (Fundação para a Ciência e Tecnologia - FCT) avalia as instituições de investigação, assim como os projetos científicos específicos. Já a agência de acreditação nacional (A3ES) avalia os programas de estudos conferentes de grau, decidindo sobre a sua primeira disponibilização ao público e a sua continuidade no tempo e, mais recentemente, avalia também as próprias instituições de ensino superior, como um todo.

O sistema de ciência, tecnologia e ensino superior português foi sujeito a uma transformação profunda desde finais do séc. XX, tanto por via legislativa como administrativa, ganhando, ao longo dos anos, crescente complexidade.

As universidades públicas passaram a ser vistas como entidades exportadoras pelos principais partidos políticos, e a sua lógica de funcionamento mudou, tendo passado a dar-se grande ênfase à internacionalização e ao estabelecimento de parcerias relevantes à escala global (SANTOS, 2005; CAETANO, 2017).

Assim, em 2018, a Faculdade de Economia da Universidade Nova de Lisboa, uma instituição pública que, desde a sua fundação, na década de 1970, procura estar na vanguarda na sua área, foi "reconstruída", com base em uma inédita parceria público-privada, que teve grande impacto político, académico e mediático. ${ }^{5}$

Esse exemplo é ilustrativo do alargamento às instituições públicas de ensino superior e ciência portuguesa de instrumentos de gestão inovadores que começaram por ser testados em outros setores do Estado e da administração, como as obras públicas e a saúde.

Nesse contexto promotor da mudança, as universidades exigem mais dos docentes. É o caso, por exemplo, da procura de registo de novas patentes, como forma de inovação e diferenciação, essenciais à sua afirmação à escala global.

5 Ver juntos estamos a construir o futuro. Nova School of Business \& Economics (2019). 
É verdade que nem tudo é novo, tendo em vista que os universitários portugueses fizeram sempre mais do que investigar e ensinar. Existe, por exemplo, uma forte tradição de colaboração dos universitários com os decisores ou potenciais decisores políticos, ${ }^{6}$ dada a sua expertise. Foi assim em ditadura ${ }^{7}$ e é assim em democracia, ${ }^{8}$ embora Garoupa (2017) sustente a ideia de que os partidos políticos portugueses deixaram de se interessar pela produção de conhecimento novo - prova disso será a fraqueza dos seus gabinetes de estudos e a sua falta de ligação a think tanks - e não atraiam académicos, nem se apoiem no seu trabalho, com reflexos negativos na qualidade da governação. ${ }^{9}$ Também o recrutamento de universitários para o exercício de funções em empresas e em organizações da sociedade civil, pela sua presumida competência e independência, ${ }^{10}$ é um fenómeno que já ocorria no séc. XX, porém, no primeiro quartel do séc. XXI, a escala é maior, visto que muitas das empresas são altamente internacionalizadas ou globais.

Realço ainda que aumentaram as exigências em relação à capacidade gestionária dos docentes, que, ainda assim, mantiveram o monopólio de exercício dos cargos académicos, com exceção do cargo de administrador. Com efeito, apesar de o Regime Jurídico das Instituições do Ensino Superior de 2007 (PORTUGAL, 2007) ter agilizado os requisitos legais de seleção dos reitores e dos diretores universitários intermédios (que passaram a poder vir de outras instituições e países, além de não terem de estar no topo da carreira para concorrerem aos cargos), continuou a exigir que tenham um perfil académico (os candidatos têm pelo menos de ser doutores). Vale, a propósito dos reitores e dos presidentes dos conselhos científicos nas universidades, o disposto, respetivamente, no artigo $86 / 3^{11}$ e no artigo 102/1/i e ii) ${ }^{12}$ da Lei n. 62/2007.

6 Adriano Moreira, um dos mais conceituados intelectuais portugueses da segunda metade do século XX e das primeiras décadas do século XXI, com uma relevante participação política, tanto em ditadura como em democracia (em 2019, com mais de 90 anos, é ainda membro do Conselho de Estado), é um defensor acérrimo da necessidade de o poder político contar com o trabalho das universidades e dos universitários para afirmação interna e externa do Estado. Ver Celso (2012). para informação detalhada do pensamento do autor sobre as funções da Universidade, ver Pinto (2017).

7 Salazar e Marcelo Caetano, líderes políticos durante o Estado Novo (1933-1974), um regime autocrático de direita, sempre recrutaram muitos académicos para o desempenho de funções políticas. Eles próprios eram professores catedráticos, respetivamente da Faculdade de Direito de Coimbra e da Faculdade de Direito de Lisboa.

8 A democracia foi instaurada na sequência da Revolução de 25 de abril de 1974.

9 Cf. Garoupa (2017).

10 É precisamente o caso de Nuno Garoupa, referido na nota anterior, que presidiu à Fundação Francisco Manuel dos Santos, uma instituição privada portuguesa que mantém fortes relações com as universidades e os universitários portugueses.

11 Que estabelece o seguinte: "Podem ser eleitos reitores de uma universidade professores e investigadores da própria instituição ou de outras instituições, nacionais ou estrangeiras, de ensino universitário ou de investigação." (PORTUGAL, 2007, on-line).

12 Assim prescreve o artigo referido "1 - No ensino universitário, nas universidades, nas suas escolas, nos institutos universitários e nas restantes instituições universitárias, o conselho científico é constituído por: a) Representantes eleitos, nos termos previstos nos estatutos e em regulamento da unidade orgânica, pelo conjunto dos: i) Professores e investigadores de carreira; ii) Restantes docentes e investigadores em regime de tempo integral, com contrato de duração não inferior a um ano, que sejam titulares do grau de doutor, qualquer que seja a natureza do seu vínculo à instituição." (PORTUGAL, 2007, on-line). 
Para uma compreensão mais fina, defino, de seguida, as dimensões analíticas da questão estudada neste artigo, como forma de saber qual é ou quais são os contextos do trabalho dos universitários portugueses, nos inícios do séc. XXI.

Analiso o trabalho dos universitários portugueses nos contextos europeu e global, porque só assim é possível compreendê-lo contemporaneamente, de um ponto de vista teórico e prático, atendendo à interligação das suas funções. Assim, como não há um ensino exclusivamente nacional, as atividades de investigação e transferência do conhecimento ligam crescentemente instituições e pessoas de países diferentes. $\mathrm{O}$ mesmo se passa em matéria de gestão, tendo em vista não existirem restrições ao exercício de quaisquer cargos em função da nacionalidade, porque isso violaria o direito da União Europeia.

É a própria natureza universal do conhecimento que se impõe nos atuais contextos socioeducativos. Aliás, nos inícios do séc. XXI, uma das estratégias de afirmação do saber humanístico, que, muitas vezes, tem que ver com particularidades nacionais ou mesmo locais, passa pela sua divulgação à escala global, de modo a permitir ou suscitar a sua comparabilidade com fenómenos de outros países.

É ainda necessário considerar as características da sociedade portuguesa dos inícios do terceiro milénio, a saber, uma sociedade aberta e capitalista, não obstante as dúvidas que possam existir sobre o futuro do capitalismo. ${ }^{13}$ Com efeito, embora o capitalismo possa estar a evoluir para a utilização de mecanismos e soluções divergentes dos tradicionais, não é plausível um regresso ao passado ou a recuperação de fórmulas antigas. Dito de outro modo: o capitalismo, tal como o conhecemos nos inícios do séc. XXI, pode ser substituído, mas só por fórmulas mais inovadoras, em meio à forte aceitação social. $\mathrm{O}$ que já ocorreu e, sobretudo, o que se anuncia em matéria de trabalho universitário, por ser radicalmente novo, exigem um forte sentido de compromisso político e social. Por outras palavras, para que a evolução jurídica e social seja consentida, é necessário que as instituições e as pessoas a conheçam e a aceitem. Então, a alternativa é ela ocorrer de forma arbitrária ou desregulada, produzindo alterações significativas na organização, no funcionamento das instituições e na vida das pessoas, não necessariamente no bom sentido.

A minha análise estrutura-se em três pontos que correspondem a três teses principais. A minha primeira tese é que o trabalho dos universitários portugueses ${ }^{14}$ depende do contexto europeu.

Entendo aqui a política como o contexto, ou seja, como um conjunto de ideias e factos que informam e conformam um determinado tempo histórico. É um facto que o contexto europeu tem conformado as políticas públicas portuguesas no séc. XXI, bastando pensar, por exemplo, no

13 Cf. Silva (2017) O autor, um antigo ministro do Ambiente do governo português, fundador do think tank Plataforma para o Crescimento Sustentável, e que, à data da escrita do presente artigo, é diretor da Cooperação para o Desenvolvimento da OCDE, dá vários exemplos de como o capitalismo está produzindo soluções novas e porventura inesperadas, como é o caso dos modelos de negócio colaborativos.

14 Por força das regras europeias e globais que garantem a liberdade de circulação de pessoas, o critério determinante para a identificação dos universitários portugueses é o vínculo laboral, ou seja, são "portugueses" todos os que trabalham em Portugal, independentemente da sua nacionalidade. Para uma análise sistemática da questão segundo o direito europeu, ver McCrudden e Prechal (2009). 
que foram as políticas de austeridade na Europa, após a crise financeira de 2007, em particular nos países intervencionados pela Comissão Europeia, pelo Banco Central Europeu e pelo Fundo Monetário Internacional, como foi o caso de Portugal. Nesse contexto específico, governos de diferentes sensibilidades políticas, como o governo de centro-direita português liderado por Pedro Passos Coelho (2011-2015) ou o governo de esquerda radical grego liderado por Alexis Tsipras (2015-), aplicaram as mesmas políticas, ou seja, as soluções exigidas pelos financiadores, de acordo com o pensamento político-económico hegemónico do governo alemão. ${ }^{15}$

Neste período, a política europeia funcionou como um fator de racionalização das políticas nacionais, tanto em matéria orçamental e financeira, de que é exemplo o caso referido, como em outras áreas, de que é exemplo a educação. Aliás, as políticas de educação são das mais europeizadas, apesar de, formalmente, serem da competência dos Estados, dada a sua relevância para o processo de integração europeia. O programa Erasmus - criado em 1987, como forma de apoio à mobilidade de professores, investigadores e estudantes europeus - é um dos melhores exemplos, se não, porventura, o melhor da Europa da liberdade de circulação de pessoas e saberes, por isso que é tão difícil pôr em causa.

Nesse contexto, é de assinalar ainda a relevância das atividades de ciência e ensino superior para a criação do mercado interno europeu, definido como o grande desígnio estratégico da União Europeia, em finais do século XX (EUROPEAN COMMISSION, 2018a). Em 2017, os montantes previstos para a investigação, a ciência e a inovação assumiram grande relevo no orçamento da União Europeia. Carlos Moedas, o comissário português titular da pasta, ficou responsável por gerir o maior programa-quadro de sempre de investigação e inovação na União Europeia, no valor de 80000 milhões de euros, para o período de 2014-2020 (ROCHA, 2014). Moedas, que se destacou como secretário de Estado adjunto do primeiro-ministro Pedro Passos Coelho, entre 2011 e 2014, no auge da aplicação das políticas de austeridade que tanto impacto tiveram nas condições de trabalho dos universitários e dos demais trabalhadores portugueses, várias vezes, referiu a importância da ciência para o desenvolvimento das economias nacionais e para a salvaguarda dos valores democráticos na Europa. Em 22 de abril de 2017, Moedas participou da "Marcha pela Ciência", em Lisboa, tendo, então, instado os cientistas que trabalhavam na Europa a "não terem medo de gritar pela ciência" e a manifestarem-se publicamente, porque, "sem ciência, não há paz, não há democracia e não há futuro." (MOEDAS, 2017, on-line).

Acresce que, em Portugal, a opinião pública defende, de forma largamente maioritária, a presença do país na União Europeia, a qual é vista como um fator de segurança e prosperidade (PARLAMENTO EUROPEU, 2018). Igual opinião tem a maior parte dos universitários portugueses ${ }^{16}$, por razões de que falarei adiante.

15 Ver Beck (2015). Em Portugal, a obra foi traduzida com o título A Europa alemã: de Maquiavel a «Merkievel». Estratégias de poder na crise do euro. Lisboa: Edições 70, 2013. No prefácio, pode ler-se que o livro "aborda a hegemonia política e ideológica da Alemanha na Europa".

16 Sobre o tema, em perspetiva ampla, veja-se o ensaio do ex-presidente da República Aníbal Cavaco Silva, ele mesmo um universitário (SILVA, 2018). 
Deve-se notar também que, após 2007, ${ }^{17}$ se assistiu a um aumento significativo da contestação pelos universitários portugueses às políticas públicas no campo do ensino superior e da ciência, que provocaram uma deterioração das suas condições profissionais. Para além das fortes restrições à progressão nas carreiras universitárias ${ }^{18}$ e do abaixamento dos salários, com impacto sobre quem detinha contratos de trabalho relativamente seguros (com ou sem tenure), foram também impostas severas restrições à entrada de novos profissionais nas carreiras nas instituições públicas. Em 2017, existiam ainda muitas pessoas no setor sem contratos de trabalho. Refiro-me principalmente a pessoas com bolsas, mas sem suficiente proteção - por exemplo, em matéria de segurança social - e sem perspetivas de futuro integradas em uma carreira específica.

Curiosamente, a exigência para a alteração da situação destes profissionais, por forma a garantir o seu acesso às carreiras académicas, com a celebração de contratos de trabalho, veio da União Europeia, ainda que não tenha sido do inteiro agrado dos sindicatos e dos trabalhadores. Fundamentalmente, a União Europeia instou os Estados a obrigarem as instituições públicas a celebrarem contratos de trabalho com todos os profissionais que exercessem funções de caráter permanente, excluindo os que exercessem funções que, por sua natureza, fossem temporárias, como era o caso dos investigadores envolvidos em projetos de duração limitada, ainda que financiados por fundos públicos. Essa visão das coisas corresponde a um ideário capitalista de ciência, visando ao aumento da produção científica europeia, de forma sustentável. Os sindicatos ficaram desagradados porque pretendiam que todos os envolvidos fossem protegidos, não apenas os que desempenhavam funções de caráter permanente.

Em 2017 e 2018, o governo português (do Partido Socialista), pressionado pelos seus parceiros parlamentares (o Bloco de Esquerda e o Partido Comunista), levou a cabo um processo de regularização dos vínculos precários na função pública, que apenas residualmente abrangeu professores e investigadores, seguindo-se a orientação europeia de não fazer contratos de trabalhos de longa duração com quem exercia funções temporárias ou de duração limitada.

A minha segunda tese é que o trabalho dos universitários portugueses depende do contexto global.

Para compreendermos o sentido e o valor do trabalho dos universitários portugueses no novo século, precisamos também conhecer as políticas de outros países e das suas instituições de ensino e investigação, nas possibilidades que oferecem desenvolvimento de carreiras. Refiro-me aos países de língua portuguesa - com destaque para o Brasil, pela sua dimensão

17 Em 9 de agosto de 2007, o banco francês BNP Paribas anunciou que iria suspender os resgates de três fundos especializados em programas de crédito titularizado, principalmente em relação a agentes dos Estados Unidos, onde se assistia já a uma crise do mercado imobiliário, com incumprimentos e baixas significativas dos preços das casas. Foi o dia em que todos perceberam que a crise também era europeia (CAETANO, 2017).

18 Refiro-me à carreira docente universitária e à carreira de investigação universitária. Sobre esse assunto, ver o que se diz infra, particularmente sobre a tendencial aproximação das carreiras na última década e as funções dos docentes universitários. 
territorial e pelo nível de institucionalização das políticas educativas -, mas também a outros, como os Estados Unidos, o Canadá e os países emergentes da Ásia e da Oceânia.

Há que destacar a colaboração entre a Fundação para a Ciência e Tecnologia (FCT), de Portugal, e a Fundação para a Coordenação de Aperfeiçoamento de Pessoal de Nível Superior (CAPES), do Brasil, visando à integração dos investigadores dos dois países nas redes globais de produção de ciência e conhecimento, para tanto, financiando projetos e bolsas. ${ }^{19}$ Assim, há que referir o importante papel que a Fundação Luso-Americana para o Desenvolvimento (FLAD) tem na promoção das relações universitárias entre Portugal e os Estados Unidos, em particular, no apoio ao intercâmbio de professores e investigadores e no apoio a projetos de pesquisa. ${ }^{20}$

Menciono ainda o crescente interesse de instituições universitárias australianas e japonesas na oferta de bolsas de estudo e no recrutamento de portugueses, em diversas áreas do conhecimento.

Essas situações se enquadram na maior disponibilidade dos universitários portugueses, sobretudo das gerações jovens, para trabalharem fora do país, seja por opção (escolhendo as instituições mais avançadas ou que lhes garantem um maior desenvolvimento pessoal e profissional), seja por necessidade (v.g., por falta de trabalho ou de trabalho seguro em Portugal).

Já as instituições portuguesas pensam também crescentemente as suas políticas em termos globais, procurando recrutar os melhores estudantes, professores e investigadores possíveis, a fim de explorar as suas vantagens competitivas.

É ainda um facto que os universitários portugueses perceberam que a sua avaliação e a progressão profissional se fazem em contextos globais e competitivos, marcados pela mudança. Prova disso é a permanente procura de adaptação aos critérios internacionais de avaliação, que, de modos diferentes, chega a todas as áreas do conhecimento.

Se há algo que podemos concluir é que essa mudança precisa de ser pensada, visto que o acelerado desenvolvimento tecnológico e das redes digitais, as mudanças culturais ligadas à valorização dos valores individuais e o enfraquecimento do poder dos Estados estão na base da globalização da ciência e do conhecimento, que já produziu importantes resultados, mas tem-se revelado, muitas vezes, desigual. Ora, é aos governos nacionais que compete combater as desigualdades com políticas socialmente justas, enfrentando os riscos associados às alterações tecnológicas e à digitalização da economia típicas do século XXI.

A minha terceira tese é que, nos inícios do séc. XXI, os contextos de atuação dos universitários portugueses são capitalistas.

19 No sítio web da FCT, em https://www.fct.pt/apoios/cooptrans/capes/2012/docs/Convenio_FCT_CAPES. pdf, está disponível o convénio-quadro de cooperação entre a FCT e a CAPES, de 30 de abril de 2010, assim como as chamadas para vários concursos. No concurso de cooperação bilateral para o biénio de 2019-2020, foram selecionados 11 projetos, conforme informação disponibilizada aqui: https://www.fct.pt/apoios/cooptrans/capes/2017/docs/Capes2019_20.pdf).

20 Os estatutos da FLAD estão disponíveis aqui: http://www.flad.pt/wp-content/uploads/2018/09/estatutos-flad.pdf. Já o plano estratégico em vigor pode ver-se aqui: http://www.flad.pt/plano-estrategico/. 
De acordo com essa premissa, Orlando de Carvalho (1926-2000), meu antigo professor na Faculdade de Direito de Coimbra, ensinava que o direito positivo deveria ser interpretado no contexto do sistema político-económico dominante (CARVALHO, 2012a, 2012b). Insuspeito de ser adepto do capitalismo, ele admitia a hipótese de sociedades desportivas, empresas privadas ou mesmo pessoas individuais poderem deter direitos económicos no âmbito de contratos de trabalho firmados por desportistas de alto rendimento, mormente futebolistas profissionais. ${ }^{21}$ Orlando de Carvalho, que, entre outras disciplinas, lecionava Direito das Empresas, Direitos de Personalidade e Teoria do Direito, mostrou-se favorável à possibilidade referida, por ela estar de acordo com o fenómeno desportivo de alta competição, no quadro do sistema capitalista, apesar das suas profundas implicações na vida das pessoas.

É um facto que a realidade universitária dos inícios do século XXI se rege por mecanismos capitalistas. Em abono desta tese, não precisamos sequer referir às multinacionais universitárias, apostadas no ensino de massas, que operam em todo o mundo, cujo objetivo principal é o lucro. Em Portugal, a sua presença nem é muito significativa, em comparação, por exemplo, com o que se passa no Brasil, embora esteja a crescer. Com efeito, as próprias universidades e os centros de pesquisa públicos, cujas missões se traduzem na promoção da ciência, da cultura e dos saberes, estão enquadradas, por regras capitalistas, na sua organização e no seu modo de funcionamento. Um exemplo desse capitalismo é a exigência feita pelo Estado português às instituições universitárias públicas para que procurem captar mais receitas próprias - ou seja, fora do orçamento do Estado -, tanto por via do aumento das receitas (taxas e preços) cobradas aos estudantes como por via da obtenção de fundos para pesquisa, em concursos competitivos (com o benefício adicional de as instituições públicas poderem cobrar overheads sobre esses valores, para o seu funcionamento normal).

$\mathrm{Na}$ segunda década do novo milénio, os dirigentes dos principais partidos políticos portugueses com responsabilidades de governo (PS, PSD e CDS)22 passaram a considerar as universidades públicas como sendo entidades exportadoras, como quaisquer empresas (PARTIDO SOCIALISTA, 2015; COLIGAÇÃO PORTUGAL À FRENTE, ${ }^{23}$ 2015). Antes disso, em 2007, na linha do que se passava noutros países, avançou-se com a possibilidade legal de as universidades públicas se organizarem segundo o regime fundacional, ou seja, segundo as regras de direito privado, por forma a terem mais liberdade, mormente na gestão dos seus mapas de pessoal. Uma década depois, foi aguerrida a discussão no meio universitário português, causada pelo Decreto-Lei n. ${ }^{\circ}$ 57/2016 do governo que previa o fortalecimento das condições de trabalho dos bolseiros ${ }^{24}$ de investigação científica por via da celebração de contratos de trabalho a

21 Em 2000, publiquei um artigo sobre esta matéria. Caetano (2000).

22 PS - Partido Socialista, de centro-esquerda; PSD - Partido Social-Democrata, de centro-direita; CDS - Partido do Centro Democrático e Social, de centro-direita.

23 A coligação Portugal à Frente foi constituída pelo PSD e pelo CDS para concorrer às eleições legislativas de 2015

24 Termo que se usa em Portugal como sinónimo do que, no Brasil, se chama "bolsista", ou seja, pessoa que aufere uma bolsa por determinada atividade de aprendizagem ou pesquisa. 
termo certo e, por fim, a sua integração em carreiras permanentes. O cerne da discussão esteve na previsão de condições diferentes de contratação para as universidades públicas sujeitas ao direito público relativamente às universidades públicas de regime fundacional, sujeitas ao direito privado. A questão transformou-se em um debate ideológico que dividiu não só os dirigentes das instituições académicas, mas também os professores e os investigadores, entre, por um lado, quem preferia soluções mais eficientes e flexíveis para as instituições e, por outro lado, quem preferia soluções mais inclusivas e seguras para os trabalhadores.

\section{DE COMO O PAPEL DAS UNIVERSIDADES ESTÁ A MUDAR}

Até agora, tenho-me referido principalmente ao papel das universidades, embora o sistema de ensino superior português seja mais amplo, albergando, para além das universidades, os chamados institutos politécnicos, que, legalmente, têm uma função mais profissionalizante do que as universidades. Com o processo de Bolonha, que, nos primeiros anos do novo século, promoveu na União Europeia a uniformização das condições de acesso aos cursos universitários e o reconhecimento dos graus académicos, essas fronteiras são, por vezes, fluidas ou imprecisas. Em todo o caso, entendo que as universidades têm uma missão específica que as distingue das demais instituições de ensino superior. Ao abordar essa ideia, refiro-me ao facto de as universidades constituírem reservatórios das ideias, dos programas e das tecnologias que podem transformar os países onde estão sediadas e o próprio mundo. Este é um papel único das universidades, por uma razão decisiva: só as universidades têm capacidade de promover, de forma sistemática, a formação de alto nível e a investigação científica em uma sociedade. Em Portugal, assim como na maior parte dos países europeus, as universidades com essa capacidade são as universidades públicas, porque as universidades privadas não dispõem de pessoas nem de meios suficientes para promover esse trabalho. A Universidade Católica é a exceção à regra, ainda que apenas em relação à parte do conhecimento, já que não compete com as mais bem apetrechadas universidades públicas portuguesas, por exemplo, no domínio das engenharias ou das ciências médicas, que exigem vultuosos investimentos. Devo, em todo o caso, notar que, de acordo com a lei portuguesa, a Universidade Católica não é uma universidade privada típica, mas uma universidade de direito concordatário, com prerrogativas que a aproximam das universidades públicas. ${ }^{25}$

Noutros países, como nos Estados Unidos, a realidade é diferente, tendo em vista que existem universidades privadas com elevada capacidade de atração de fundos privados, o que

25 Nos termos da Concordata celebrada entre a República Portuguesa e a Santa Sé, a Universidade Católica Portuguesa se beneficia de algumas vantagens e prerrogativas. Por exemplo, o reitor desta instituição faz parte do Conselho de Reitores das Universidades portuguesas com os reitores das universidades públicas, embora a instituição não tenha financiamento público. Hoje é usual dizer-se que é uma instituição de direito concordatário, embora, no passado, tenha-se defendido, muitas vezes, que era uma universidade pública não estatal. A Universidade Católica goza de prestígio, sobretudo na área da economia e das finanças, em que ocupa um lugar de relevo internacional. 
lhes permite ocupar lugares de topo nos rankings mundiais das universidades. ${ }^{26} \mathrm{Na}$ Europa, só o modelo britânico se aproxima do estadunidense, porque, nos demais países, prevalecem as instituições públicas de ensino superior. Deve-se notar, porém, que, em alguns países europeus, estas começam a enfrentar dificuldades de financiamento crescentes. A União Europeia dispõe de fundos avultados para investir em ciência e inovação, mas aposta essencialmente em projetos transnacionais. Paulatinamente, vêm-se construindo na Europa sistemas de financiamento das instituições públicas de ensino superior e investigação de caráter misto, com financiamento público e privado, sendo muito competitivos. Nesse novo contexto político, económico, tecnológico e financeiro, os agentes universitários comportam-se diferentemente em relação ao passado, procurando internacionalizar as suas atividades e fazer parte de grandes projetos multinacionais, que captam o grosso dos financiamentos. Esses projetos estão sujeitos a hierarquias específicas, muitas vezes, distintas das hierarquias das instituições de origem (nem sempre são os professores no topo das carreiras que ganham os projetos), suscitando muitos comportamentos individuais antissistema e promovendo a mudança.

Essa é a realidade que existe, e é importante procurar perceber a sua dinâmica, assim como qual é o papel de Portugal e dos universitários portugueses.

Segundo Ravara (2017), diretor do Gabinete de Agronegócios da Caixa Geral de Depósitos (CGD), Portugal é um país grande em miniatura. ${ }^{27} \mathrm{~A}$ sua tese é a de que, pela sua diversidade paisagística, Portugal é capaz de atrair turistas de todo o mundo e, desse modo, vender os produtos nacionais nos mercados internacionais. A estratégia da CGD, como banco público português, consiste em financiar os projetos empresariais relevantes ao serviço do interesse nacional. Aplicada à política universitária, esta estratégia significa que Portugal deve apoiar as universidades, porque precisa delas para se afirmar internacionalmente. Com esse entendimento, defendo há vários anos a ideia de que as universidades e os centros de pesquisa exercem no séc. XXI uma nova função de soberania que consiste na formação das pessoas e na produção de conhecimento que possa ser mobilizado pelos decisores políticos e pela sociedade para finalidades de interesse geral. Teoricamente, não faz sentido diferenciar as instituições em função da sua natureza pública ou privada, mas em função da sua capacidade. As características das instituições dizem muito delas: uma universidade global é diferente de uma universidade regional, assim como uma universidade de ensino é diferente de uma universidade de ensino e investigação. Em todo o caso, o que é determinante são os meios de que cada instituição em concreto dispõe e a sua organização. Ora, nesta matéria, assim como na maior parte dos países europeus, em Portugal, as universidades podem desempenhar um papel essencial, mas, para isso, é necessário não só mais investimento público, mas investimento inteligente, como o que fez o governo alemão com a sua estratégia de criação de universidades de excelência, capazes de competir internacionalmente. Um país com as

26 Em 2017, o abaixamento desse financiamento implicou uma perda de posições em alguns rankings internacionais.

27 Cf. Filipe Ravara, "Portugal é um país grande em miniatura" (RAVARA, 2017). 
características de Portugal assemelha-se mais à Alemanha do que aos Estados Unidos, sendo que as políticas públicas de apoio à internacionalização das universidades e os seus centros de investigação têm evidentes reflexos sobre o trabalho e a produtividade dos universitários.

\section{PREPAREMO-NOS PARA OS FOGOS QUE INEVITAVELMENTE VIRÃO}

E não poderão os universitários ser substituídos por pessoas igualmente eficientes e cujos serviços sejam mais baratos? Creio que não, dando um exemplo demonstrativo do que afirmo. Em 17 de junho de 2017, um fogo de grandes dimensões matou 64 pessoas nos municípios de Pedrógão Grande, Castanheira de Pera, Ansião, Alvaiázere, Figueiró dos Vinhos, Arganil, Góis, Penela, Pampilhosa da Serra, Oleiros e Sertã, na região centro de Portugal. Em 15 de outubro do mesmo ano, cerca de 500 fogos que ocorreram em simultâneo em 27 municípios dos distritos de Viseu, Guarda, Castelo Branco, Aveiro e Leiria, também na região centro do país, provocaram a morte a mais 45 pessoas. Os incêndios produziram ainda centenas de feridos e desalojados, para além de prejuízos muito significativos (LUSA, 2017a).

Para apurar o que se passou, tal como exigido pelo presidente da República Portuguesa (LUSA, 2017b), Marcelo Rebelo de Sousa, em 10 de julho desse ano, a Assembleia da República (parlamento) decidiu constituir uma comissão de peritos, que foram escolhidos, em partes iguais, pelos partidos políticos com assento parlamentar e pelo Conselho de Reitores das Universidades Portuguesas (CRUP). ${ }^{28}$ Como o modelo permitia adivinhar, foram escolhidos na sua maioria peritos ligados a universidades e a centros de investigação de referência, sendo que, para presidente da Comissão, foi escolhido um ex-Reitor de uma universidade pública portuguesa. $^{29}$

Os relatórios produzidos provam que houve descoordenação das forças policiais e de segurança interna. Mais se sabe que a floresta portuguesa não está suficientemente ordenada, com o predomínio de espécies que favorecem a propagação dos incêndios (pinheiro e eucalipto). (COMISSÃO TÉCNICA INDEPENDENTE, 2017, 2018).

Como podemos ler esse facto?

É célebre a afirmação de Chesterton de que, quando as coisas correm muito mal, não precisamos de um pragmático, mas de um teórico, porque o pragmático só conhece a prática

28 A denominada Comissão Técnica Independente foi criada pela Lei n. 49-A/2017, de 10 de julho (Portugal, 2017), com a missão de determinar com celeridade as causas da tragédia. A composição da comissão é definida pelo artigo 1.\%/2, que estabelece que "A Comissão é composta por doze técnicos especialistas de reconhecido mérito, nacionais e internacionais, com competências no âmbito da proteção civil, prevenção e combate aos incêndios florestais, ciências climáticas, ordenamento florestal, comunicações e análise de risco". O artigo 1.\%/3 estabelece o modo de designação: "Os membros da Comissão são designados do seguinte modo: a) Seis peritos designados pelo Presidente da Assembleia da República ouvidos os Grupos Parlamentares; b) Seis peritos indicados pelo Conselho de Reitores das Universidades Portuguesas e designados pelo Presidente da Assembleia da República, um dos quais é o presidente. A Lei n. 109-A/2017, de 14 de dezembro (Portugal, 2017), determinou a competência da mesma comissão para a investigação das causas dos fogos de outubro.

29 João Guerreiro, antigo reitor da Universidade do Algarve (2006-2009). 
do dia a dia, ou seja, o modo como as coisas habitualmente funcionam. Quando as coisas não funcionam, a sociedade tem de recorrer a quem tem conhecimento da razão pela qual elas funcionam. Para desconstruir a ideia feita de que as sociedades não necessitam de pessoas que pensem, de pessoas que as orientem e organizem ou, até, de que há espaço para o desleixo ou para que se viva apenas o lado bom da vida, sem sacrifícios ou dificuldades, Chesterton escreveu o que se tornou um verdadeiro aforismo: "É má ideia tocar harpa enquanto Roma está a arder; mas é uma excelente ideia estudar hidráulica enquanto Roma está a arder." (CHESTERTON, 2013, p. 17). Inspirado no autor inglês, o filósofo do Direito, constitucionalista e cientista político português Paulo Ferreira da Cunha publicou, em 2005, um livro intitulado "Escola a arder. Debates e diálogos", no qual discute os grandes problemas das universidades no século XXI. Tendo escrito o livro na qualidade de cidadão e sindicalista empenhado nas questões universitárias do seu tempo, Paulo Ferreira da Cunha assumiu-se contra a depauperação da carreira universitária, mas também contra o abaixamento da qualidade dos estudantes, a eliminação das disciplinas de formação geral (filosóficas, históricas e políticas) nos cursos de graduação em Direito, a burocratização da vida universitária, etc.

O livro foi escrito em um período de transição, a que já me referi, quando o Estado português procedeu, em articulação com os parceiros europeus, à harmonização das condições de obtenção e reconhecimento de graus académicos no espaço europeu (União Europeia, Noruega e Suíça) e à alteração dos modelos de organização das instituições de ensino superior, com a incorporação de elementos típicos das universidades anglo-saxónicas. Para dar um exemplo, em Portugal, com a aprovação, em 2007, do Regime Jurídico das Instituições de Ensino Superior (RJIES), ${ }^{30}$ os órgãos representativos das universidades e dos institutos politécnicos (Assembleia de Representantes, Senado, etc.) deixaram de ser estruturas de natureza paritária (com igual número de professores/investigadores, estudantes e trabalhadores não docentes) para passaram a ter, em um novo órgão chamado Conselho Geral, uma participação reduzida de estudantes e trabalhadores não docentes contrabalançada pela entrada de membros da sociedade civil. Com a reforma legislativa, os professores/investigadores passaram a ter a maioria dos lugares nos conselhos gerais das instituições de ensino superior, equivalente ao dobro do número dos membros externos, mas o presidente do órgão passou a ter de ser necessariamente um membro externo.

O Conselho Geral passou a ter como funções principais a aprovação dos instrumentos orientadores da governação das universidades, assim como a eleição do Reitor. Já as funções deste se mantiveram praticamente inalteradas.

Em termos comparados, assistiu-se à incorporação no sistema universitário português de elementos típicos das universidades anglo-saxónicas, em particular das americanas, se bem que os contextos de atuação das universidades portuguesas sejam muito diferentes. Como já fiz referência, na maioria dos países europeus, incluindo Portugal, as universidades de referência são universidades públicas, não instituições privadas. A especificidade

30 Lei n. $^{\circ}$ 62/2007, de 10 de setembro (PORTUGAL, 2007). 
estadunidense explica a cooptação de membros da sociedade para os órgãos de gestão das universidades, o que, podendo justificar-se na Europa, só resultará se os membros externos defenderem ativamente os interesses das instituições. Em Portugal, os críticos da reforma legislativa de 2007 falam do papel menor dos conselhos gerais, que supostamente pouco mais fazem do que eleger o Reitor. Essa tese é corroborada pelos sindicatos, mesmo por um sindicato transversal em termos ideológicos como é o Sindicato Nacional do Ensino Superior (SNESup), que, em 2017 (REVISTA ENSINO SUPERIOR, 2017), publicou um volume totalmente dedicado a esse tema.

Em termos teóricos, os conselhos gerais das universidades gozam de amplas competências que estão muito para além da eleição do Reitor. A questão está nas implicações que a reforma de 2007 teve a jusante, em termos de transformação do modo de funcionamento das universidades e das mentalidades dos agentes. Se as políticas públicas forem erradas, fazem perigar todo o sistema, sendo essa a situação denunciada no livro. Paulo Ferreira da Cunha funciona como o homem sábio que denuncia os erros do sistema, mas não se substitui a quem tem a responsabilidade de tomar as medidas certas. Essa função é muito importante em democracia. No caso em apreço, a crítica é feita por um universitário, o que faz sentido, porque é de seu interesse intervir.

\section{PARA ONDE OS UNIVERSITÁRIOS PORTUGUESES QUEREM IR E PARA ONDE VÃO EFETIVAMENTE}

Neste contexto, importa saber para onde os universitários portugueses querem ir e para onde vão efetivamente.

Como já vimos, ciente da necessidade de dotar as universidades públicas de meios financeiros, técnicos e humanos capazes de lidar com a mudança de sistema, o legislador português, em 2007, através da já referida Lei n. 62/2007, abriu a possibilidade de aquelas, sob proposta dos respetivos Reitores e da aprovação dos Conselhos Gerais, optarem, em termos de organização e funcionamento, por um regime fundacional, em substituição do regime tradicional. A opção pelo regime fundacional obedece a critérios mais exigentes em termos de percentagem de verbas próprias das universidades, mas dá mais liberdade às instituições em matéria, por exemplo, de contratação de pessoas (docentes, investigadores e trabalhadores não docentes), com a sujeição a regimes de direito privado $^{31}$ e a adequação às necessidades concretas.

Não há dúvidas de que o papel dos Estados e das universidades está a mudar significativamente, mas as opiniões dividem-se. Em Portugal, algumas universidades públicas optaram pelo regime fundacional - Universidades do Porto, do Minho, de Aveiro e Nova de Lisboa. Já a Universidade de Lisboa, que resultou da fusão, em 2013, da Universidade (Clássica) de

31 Que fique claro que não se trata de as universidades poderem deixar de ser públicas, mas sim de poderem ficar sujeitas a regras de direito privado. Para maiores desenvolvimentos, veja-se a discussão no já referido volume do SNESup. 
Lisboa com a Universidade Técnica de Lisboa, tem um estatuto semelhante ao de fundação, que lhe foi outorgado pelo decreto governamental que a constituiu. Porém, outras universidades enfrentaram muitas dificuldades para mudar de regime e não o fizeram. Foi o caso da Universidade de Coimbra. Em 2017, o então reitor, João Gabriel Silva, defendeu a passagem da universidade à fundação, mas os professores e os investigadores eleitos para o Conselho Geral rejeitaram, por larga maioria, essa possibilidade. Em 11 julho de 2017, o reitor da Universidade de Coimbra, em uma longa mensagem que enviou a toda a academia, na sequência da promulgação pelo presidente da República do decreto-lei do governo sobre o emprego científico, voltou a insistir na conveniência da adoção de um regime fundacional como forma de resistir ao - em sua opinião - maior ataque até aí perpetrado pelo poder político contra as universidades públicas (GOMES, 2017). Em causa, estava a exigência governamental de se integrar nos mapas permanentes de pessoal das universidades, com contratos de seis anos, os pesquisadores que houvessem feito parte de projetos de pesquisa de duração inferior, sem que houvesse intenção do governo de reforçar o financiamento público das universidades. A razão do interesse do reitor da Universidade de Coimbra para que esta adotasse o regime fundacional se prendia com o facto de as universidades sujeitas a esse regime poderem fazer contratos de trabalho ajustados ao tempo de participação dos investigadores nos projetos ou à existência de financiamento disponível. O reitor da Universidade de Coimbra defendeu ainda a necessidade de admitir mais professores e investigadores, mas com financiamento adequado, de acordo com o planejamento estratégico da própria universidade. Por fim, João Gabriel Silva sustentou que a dependência excessiva das universidades em relação ao financiamento externo e, em particular, ao financiamento por via da participação em projetos, favoreceria determinadas áreas do conhecimento em detrimento de outras, à revelia da vontade das instituições, dando como exemplo o facto de os profissionais das ciências sociais e das humanidades receberem muito menos dinheiro por via da sua participação em projetos do que os profissionais das ciências exatas e tecnológicas. Em sua opinião, essa excessiva sujeição às regras do mercado, contra a autonomia das universidades, era uma das razões para que muitos professores e pesquisadores rejeitassem o regime fundacional.

Mas não será essa sujeição ao mercado inevitável no mundo em que vivemos? Ou será necessariamente prejudicial?

Nos inícios do século XXI, muitos professores e investigadores em Portugal opuseram-se à ideia de as universidades poderem adotar estruturas de caráter empresarial, mormente de natureza fundacional (FERNANDES et al., 2008); em sentido contrário, defendendo as universidades-fundação (MOREIRA, 2017). Já o ex-reitor da Universidade de Lisboa António Sampaio da Nóvoa continua a não aceitar o princípio da reforma bolonhesa de que as universidades devem ter como objetivo a empregabilidade dos seus estudantes, porque, em sua opinião, isso implica o abandono do ideal universitário de procura do saber. A prova disso seria o abandono das disciplinas de formação geral em detrimento dos interesses das 
empresas e do mercado (SANTOS, 2012;32 NÓVOA, 2018).

Como já fiz referência , é um facto que, no presente século, a ação das universidades se inscreve em contextos de caráter capitalista, seja um capitalismo liberal, como no caso português, seja um capitalismo de Estado, como no caso chinês e no de outras economias asiáticas em ascensão.

Refiro-me propositadamente à economia porque, no século XXI, não se pode falar de universidades sem se falar de economia (CARAÇA; CONCEIÇÃO; HEITOR, 1996). É inquestionável que as pessoas comuns dão muita atenção à empregabilidade dos cursos. Já não são apenas os pais que se preocupam com os empregos dos filhos, mas os próprios filhos, que têm acesso a mais e melhor informação e podem fazer escolhas. Longe vai o tempo em que eram os governos que determinavam as escolhas das pessoas em matéria de ensino. Além dos jovens que procuram formação que os habilite a terem um emprego, existem cada vez mais adultos que necessitam de qualificação, para ascenderem na carreira ou para garantirem o seu posto de trabalho (CAEIRO; CAETANO, 2019). Acresce que as próprias instituições universitárias sofrem de um excesso de capacidade instalada, por causa da crise demográfica, pelo que necessitam chegar a novos públicos com propostas formativas atrativas (LORI; CAETANO, 2011). Já fiz referência ao fato de que os partidos políticos portugueses mais representativos entendem hoje que as universidades produzem bens transacionáveis, ou seja, bens exportáveis e, por isso, defendem que devem ser apoiadas pelo governo e pela agência pública de promoção do comércio externo (AICEP), tal como qualquer empresa. Se não é por convicção que os agentes universitários se reajustam a essa nova circunstância, é por necessidade, dada a redução do financiamento público das instituições e a diminuição do número de estudantes. Perante essa situação, as universidades apostam na captação de estudantes no exterior e na formação de adultos, na linha do que vêm recomendando instituições internacionais de referência no campo económico e da educação como a Comissão Europeia, a OCDE e a UNESCO. A alternativa é a redução da capacidade instalada das instituições de ensino superior, com o despedimento de professores, o que as instituições não querem fazer, mas podem ser forçadas a fazer (EUROPEAN COMMISSION, 2018; OECD, 2018; UNESCO, 2018). Ainda no quadro da mesma política visando ao aumento do número de estudantes ou formandos e, por essa via, ao aumento das receitas, as universidades procuram recorrer a uma "mão de obra" mais flexível, por exemplo, por meio da realização de contratos com professores a tempo parcial ou mediante convite. Basicamente, as universidades portuguesas procuram fugir a responsabilidades permanentes com o seu pessoal, em particular com os seus professores e investigadores, por razões financeiras, mais até do que por razões de competitividade internacional, dado que não se pode aumentar a oferta formativa sem professores e não pode haver ensino de qualidade sem uma investigação de base que a sustente.

Volto a destacar que, no caso português, estão em causa, sobretudo, as universidades

32 Trata-se de uma entrevista realizada em 2012 ao então reitor da Universidade de Lisboa. A entrevista foi feita Lucíola Santos, professora da Faculdade de Educação da Universidade Federal de Minas Gerais, e publicada na revista Educação e Sociedade. 
públicas, mais do que as universidades privadas cujo compromisso com a investigação é menor e, além disso, podem ser encerradas facilmente, até porque o poder sindical nessas instituições é baixo.

Se os universitários podem e devem ser uma elite generosa, porque têm uma missão pública a cumprir, não devem ter a ilusão de que as coisas acontecem porque têm de acontecer.

Na discussão política ocorrida em Portugal, a que já aludi sobre os termos da integração dos trabalhadores precários na administração pública, é interessante perceber de que modo o legislador encara os professores e os investigadores universitários.

Convém notar que, por precário na administração pública, se entende todo o trabalhador que não dispõe de um vínculo profissional estável. Os termos da discussão pública em Portugal andaram à volta de dois pontos: definir o que eram necessidades permanentes para efeitos de contratação dos precários e saber quem estava abrangido pelas regras legais.

Não houve dúvidas de que as universidades estavam abrangidas pela legislação, no que se referia aos trabalhadores não docentes. Mas existiram (no tempo em que escrevemos, existem ainda) muitas dúvidas sobre se os docentes e os investigadores estavam ou não abrangidos. Para além das dúvidas legítimas sobre o que dizia a lei, os agentes políticos e universitários manifestaram posições contrárias sobre a política que deveria ser prosseguida.

Se os sindicatos do ensino superior recomendaram aos seus associados que submetessem as suas candidaturas ao programa de integração dos trabalhadores precários sempre que entendessem que reuniam os pressupostos legais, não faltou - por exemplo, entre os reitores - quem viesse dizer que não era do interesse das universidades recrutar pessoas que não fosse pela via de concursos gerais que garantissem a entrada dos melhores e não necessariamente dos que já estavam no sistema com vínculos precários.

Volto a referir ao fato de que, nesta matéria, a União Europeia foi quem primeiro instou os Estados-membros a regularizarem a situação dos professores e dos pesquisadores que exercessem funções de caráter permanente, com exclusão dos que exercessem funções que, por sua natureza, fossem temporárias - por exemplo, em projetos financiados.

Trata-se de uma situação complexa porque existe um trade-off entre, por um lado, dar um estatuto de maior estabilidade a quem já trabalha em uma instituição, porventura há muitos anos, ainda que, em uma situação precária, e, por outro lado, recrutar pessoas em função do seu mérito, aferido, por exemplo, pelo número de publicações internacionais em revistas de referência. Segundo este último critério, quem está em melhores condições de ganhar um concurso para professor ou investigador é quem passou os últimos anos da sua vida a investigar, muitas vezes, também em situação precária. Já quem se dedicou a ensinar ou a exercer outras funções (v.g., de gestão) teve menos tempo para investigar e tem menos condições de ser escolhido. Estamos, em ambos os casos, perante situações de relativa precariedade que competem entre si para conquistar lugares escassos.

Há ainda outros dois objetivos das universidades potencialmente contraditórios que 
podem repercutir sobre a qualidade do sistema de ensino e investigação e sobre as vidas dos profissionais envolvidos: ter mais estudantes, desenvolvendo para o efeito programas agressivos de atração de interessados nacionais ou internacionais, o que exige mais horas de trabalho docente; ou ter maior produção científica, o que exige uma diminuição das responsabilidades docentes.

Embora existam, em Portugal, instituições exclusivamente de investigação, a maior parte é de ensino e investigação. Ora, o ECDU define as já referidas quatro funções dos docentes universitários, pelas quais estes são avaliados: investigação, docência, transferência do conhecimento e gestão universitária.

Como se pode fazer tudo isso ao mesmo tempo e bem? Como garantir que os universitários (professores, cientistas) participam da função de soberania a que me referi anteriormente?

A par de uma depauperação da carreira universitária ("congelamento" dos salários, não abertura de concursos de progressão na carreira, etc.), assistiu-se ao aumento das exigências sobre os professores, que devem exercer cabalmente as quatro funções.

Apesar de o ECDU reconhecer as quatro funções em plano de igualdade, não existe consenso sobre o que é esperado dos professores. Além disso, embora os regulamentos de avaliação do desempenho de algumas universidades estabeleçam perfis funcionais diferenciados que garantem a possibilidade de alguma especialização ou dedicação prioritária a uma das funções (por exemplo, investigação ou gestão universitária), existe um intenso espaço de incerteza que prejudica, sobretudo, os melhores profissionais, pela já referida insuficiente abertura de concursos para entrada ou progressão na carreira.

Com a insuficiência de meios para dar a cada uma das pessoas que está no sistema o que merece e para atrair pessoas de mérito que estão fora do sistema, a saída para o exterior é inevitável, porém normalmente saem os melhores. É importante mencionar que a saída para o exterior, se é que faz sentido falar em exterior em um mundo globalizado, pode ser boa, tanto que, muitas vezes, é deliberada. Com efeito, muitos dos melhores professores e pesquisadores, precisamente porque são bons, preferem mover-se, o que temos também de reconhecer é, desde sempre, o o movimento próprio dos universitários. Podemos até dizer que a globalização não é má para os melhores, ainda que possa ter custos pessoais e familiares para uma pessoa mover-se. Não é, aliás, por acaso, que muitas das pessoas que se movem são jovens ou não têm responsabilidades familiares. O ponto essencial, porém, não é esse, porque qualquer país almeja ter um lugar privilegiado no processo de globalização ou na organização regional de que faz parte, e isso só é possível fixando os melhores, independentemente do seu país de origem. Passa-se nesta matéria o mesmo que se passa no desporto de alta competição, como é o caso do futebol: os melhores clubes do mundo são os que atraem os melhores futebolistas, não importando a sua nacionalidade. Já perceberam isso os potentados europeus em termos de desporto, mas também, em outro nível de afirmação, a China. Ora, por muito que se goste de futebol e de desporto, tem de se reconhecer que o papel dos universitários no 
mundo não é menor, porém será maior. Curiosamente, o desempenho dos futebolistas portugueses é, em termos relativos, superior aos dos universitários portugueses, como se comprova pela posição dos clubes e das universidades portugueses nos rankings europeus e mundiais respetivos.

\section{CONCLUSÕES}

Este artigo teve como objetivo perceber o significado do trabalho dos universitários portugueses nos inícios do séc. XXI. Diante disso, procurei responder às seguintes questões: o que é o trabalho universitário? Quem são os trabalhadores universitários? De que modo se comportam e por quê?

Após ter definido os professores e os investigadores como o objeto do meu estudo, comecei por verificar o que diz a lei portuguesa relativamente às suas funções. Da interpretação que faço do artigo $4^{\circ}$ do ECDU decorre que as quatro funções dos universitários (investigação, docência, transferência do conhecimento e gestão) são igualmente importantes, sem prejuízo de, conforme as necessidades das universidades e as preferências dos interessados devidamente justificadas, poder haver especialização funcional, por períodos mais ou menos longos.

Analisei os contextos em que o trabalho dos universitários portugueses tem lugar, apoiando-me em abundantes factos, tendo chegado a várias conclusões.

Em primeiro lugar, concluo que só é possível pensar as universidades a partir do trabalho dos universitários. No que se refere especificamente a resultados e processos, verifica-se que as universidades dependem do desempenho dos seus professores e dos seus investigadores, para que elas próprias sejam bem avaliadas pelas autoridades competentes.

Em segundo lugar, mostro que se acentuam, de diversos modos, as características capitalistas do sistema de ciência, ensino superior e inovação em Portugal, com reflexos na forma como o trabalho universitário é levado a cabo. Ao mesmo tempo que se assiste ao aumento das exigências de desempenho dos agentes, agravam-se os problemas de carreira, mantendo-se muitas situações de precariedade.

Em terceiro lugar, concluo que dos universitários portugueses se espera que deem as respostas de que o mundo precisa, o que é muitíssimo. Essa situação decorre também do facto de que todas as ações relevantes devem ser feitas à escala global, não bastando que sejam pensadas ou executadas em escalas menores.

Em um período histórico em que temos, teoricamente, uma ligação facilitada uns aos outros, corremos o risco de estar mais isolados do que nunca.

As duas grandes ameaças que impendem sobre a humanidade são a guerra atómica e a pobreza extrema. Em uma sociedade forte, os universitários têm o poder que lhes advém do saber. Por isso é preciso que sejam ouvidos, mas, sobretudo, é preciso que façam ouvir a sua voz, de forma a garantir a paz e a segurança dos povos.

Até ao final da I Guerra Mundial, o poder das nações era aferido, sobretudo, pela 
sua capacidade militar. No séc. XXI, o poderio militar continua a ser muito importante, mas não basta para que uma nação seja poderosa. A hierarquia das potências no nosso tempo não decorre apenas do seu poder militar, mas também da sua capacidade económica, científica e cultural. Tudo isso deve fazer parte de uma estratégia pública que garanta saber e saber-fazer.

Em um mundo globalizado, como é o nosso, o poderio das nações advém da sua capacidade de participação no processo de transformação do mundo, o que depende não só do trabalho, mas também da voz dos universitários. Por outras palavras, de um trabalho que tenha como destinatária a sociedade e que seja por esta valorizado.

Muitos são os universitários que aconselham o poder político, assim como há outros que se envolvem na política. Outros exercem uma crucial função de crítica, advertindo para o que está mal na política e na sociedade. Outros ainda são chamados a encontrar soluções para os tais problemas graves, como se viu no pedido de apoio aos universitários portugueses após a catástrofe dos fogos de 2017.

Por último, mas não menos importante, concluo pela importância do trabalho universitário para a afirmação da identidade portuguesa, nos contextos europeu e global. A Presidência Portuguesa da União Europeia, em 2000, dedicou especial atenção à temática da educação e às suas implicações na transformação da Europa e do mundo. Dos documentos de base da Presidência, destaco o documento intitulado "Para uma Europa da Inovação e do Conhecimento. Emprego, Reformas Económicas e Coesão Social” (LISBOA, 2000) coordenado por proeminentes cientistas sociais europeus. ${ }^{33}$ Manuel Castells, um dos autores, errou na sua análise de que as religiões ou as culturas europeias não seriam fontes de identidade europeia, mas sim o patriotismo constitucional dos cidadãos europeus, ou seja, o seu respeito pela democracia.

A crise europeia posterior a 2007 mostra que assim não é, ou seja, que os europeus continuam muito divididos, a ponto de se suspeitar do domínio da União Europeia pela Alemanha - o perigo de uma Europa alemã para o qual advertiu Beck.

Essa reflexão é importante porque nos permite olhar para a evolução dos sistemas de ciência, ensino superior e inovação, na perspetiva do trabalho dos universitários. Dado que o seu papel na formação das pessoas é essencial, é preciso lutar por soluções jurídicas que, não impedindo a natural evolução e mudança de concepções sobre o que é o trabalho universitário, garantam que professores e investigadores continuam a promover a defesa da casa humana comum.

33 Robert Boyer, Manuel Castells, Gosta Esping-Andersen, Robert Lindley, Luc Soete e Maria João Rodrigues. 


\section{REFERÊNCIAS}

BECK, Ulrich. A Europa alemã: de Maquiavel a «Merkievel». Estratégias de poder na crise do euro. Lisboa: Edições 70, 2013.

BECK, Ulrich. A Europa alemã: a crise do euro e as novas perspectivas de poder. Rio de Janeiro; São Paulo: Paz e Terra, 2015.

CAEIRO, D. J. A.; CAETANO, J. C. R. Políticas de inovação e qualidade no ensino superior (a distância) em Portugal: o papel dos atores num sistema de governação complexo. Trabalho \& Educação, Belo Horizonte, v. 28, n. 1, p. 199-217, 21 fev. 2019. Disponível em: https://periodicos.ufmg.br/index.php/trabedu/article/view/9867. Acesso em: $21 \mathrm{fev}$. 2019.

CAETANO, Edgar. 9 de agosto de 2007. O dia em que "o mundo mudou". Observador, Lisboa, 9 ago. 2017. Disponível em: https://observador.pt/especiais/9-de-agosto-de-2007-o-dia-em-que-o-mundo-mudou/. Acesso em: 23. jan. 2019.

CAETANO, J. C. R. A Universidade no século XXI. Revista Internacional d'Humanitats, CEMOrOc-Feusp / Univ. Autònoma de Barcelona, v. 39 , p. 55-64, jan./ abr. 2017.

CAETANO, João Relvão. Penhor da posição contratual de desportista profissional. Discursos: Estudos em Homenagem a Luís Sá, Lisboa, S. 3, no especial, p. 269-295, 2000.

CARAÇA, J. M. G.; CONCEIÇÃO, P.; HEITOR, M. V. Uma perspectiva sobre a missão das Universidades. Análise Social, Lisboa, v. 31, n. 139, p. 1201-1233, 1996. Disponível em: http://analisesocial.ics.ul.pt/documentos/1223396575R0tIQ8js9Iy17FX8.pdf. Acesso em: 28 jan. 2019.

CARVALHO, Orlando de. Direito das empresas. Coimbra: Coimbra Editora, 2012a.

CARVALHO, Orlando de. Direito das coisas: do direito das coisas em geral. Coimbra: Coimbra Editora, 2012b.

CELSO, M. Adriano Moreira vê obrigação da Universidade em compreender atual desordem mundial. Antena 1, Lisboa, 2012, 16 out. 2012. Disponível em: https://www.rtp.pt/ noticias/economia/adriano-moreira-ve-obrigacao-da-universidade-em-compreender-atual-desordem-mundial_a595751. Acesso em: 12 mar. 2019.

CHESTERTON, Gilbert Keith.Disparates do Mundo. Lisboa: Alêtheia Editores, 2013.

COligAÇÃO PORTUGAL À FRENTE. Agora Portugal pode mais. Programa eleitoral. (Eleições legislativas 2015). Lisboa: out. 2015. Disponível em: https://www.dn.pt/DNMultimedia/DOCS +PDFS/Portugal\%20\%C3\%80\%20Frente\%20-\%20Agora,\%20Portugal\%20pode\%20mais.pdf. Acesso em: 21 fev. 2019 
COMISSÃO TÉCNICA INDEPENDENTE, Relatório. Lisboa: Assembleia da República, out. 2017. Disponível em: https:/www.parlamento.pt/Documents/2017/Outubro/ Relat\%C3\%B3rioCTI_VF\%20.pdf. Acesso em: 26 jan. 2019.

COMISSÃO TÉCNICA INDEPENDENTE, Relatório. Lisboa: Assembleia da República, mar. 2018. Disponível em: https://www.parlamento.pt/Documents/2018/Marco/RelatorioCTI190318N.pdf. Acesso em: 26 jan. 2019.

\section{EUROPEAN COMMISSION/EACEA/EURYDICE. The European Higher Education}

Area in 2018: Bologna Process Implementation Report. Luxembourg: Publications Office of the European Union, 2018a. Disponível em: https:/eacea.ec.europa.eu/national-policies/eurydice/sites/eurydice/files/bologna_internet_0.pdf. Acesso em: 31 jan. 2019.

\section{EUROPEAN COMMISSION/EACEA/EURYDICE. The European Higher Education} Area in 2018: Bologna Process Implementation Report. Luxembourg: Publications Office of the European Union, 2018b. Disponível em: https://eacea.ec.europa.eu/national-policies/eurydice/sites/eurydice/files/bologna_internet_0.pdf. Acesso em: 31 jan. 2019.

FERNANDES, J. P. A. et al. A reforma das universidades. $O$ processo de Bolonha e o futuro da universidade. Le monde diplomatique. Edição portuguesa, Lisboa, 16 jan. 2008. Disponível em: https://pt.mondediplo.com/spip.php?article. Acesso em: 30 jan. 2019.

FUNDAÇÃO PARA A CIÊNCIA E A TECNOLOGIA (PORTUGAL). Convénio-quadro de cooperação entre a FCT e a CAPES. Lisboa/Brasília: FCT, 30 abr. 2010. Disponível em https://www.fct.pt/apoios/cooptrans/capes/2012/docs/Convenio_FCT_CAPES.pdf: Acesso em: 19 jan. 2019.

GAROUPA, Nuno. O regresso das claques. Diário de Notícias, Lisboa, 8 ago. 2017. Disponível em: http://www.dn.pt/opiniao/opiniao-dn/nuno-garoupa/interior/o-regresso-das-claques-8690825.html. Acesso em: 8 fev. 2019.

GOMES, João Francisco. Reitor de Coimbra critica "mais grave atentado contra a escola pública em toda a democracia portuguesa”. Observador, Lisboa, 12 jul. 2017. Disponível em: https://observador.pt/2017/07/12/reitor-de-coimbra-critica-mais-grave-atentado-contra-a-escola-publica-em-toda-a-democracia-portuguesa/. Acesso em: 8 fev. 2019.

LORI, N. F.; CAETANO, J. C. R. O contexto da competitividade internacional para as universidades portuguesas. Revista da Associação Portuguesa de Sociologia, Lisboa, n. 2, p. 423-442, 2011. Disponível em: https://revista.aps.pt/pt/o-contexto-da-competitividade-internacional-para-as-universidades-portuguesas/. Acesso em: 28 jan. 2019.

LUSA. 2017/Incêndios: mais de 100 mortos no pior ano de fogos em Portugal, TSF, Lisboa, 4 dez. 2017a. Disponível em: https://www.tsf.pt/lusa/interior/2017incendios-mais-de-100-mortos-no-pior-ano-de-fogos-em-portugal-8961300.html. Acesso em: 12 fev. 2019. 
LUSA. Pedrógão Grande: Marcelo defende que tragédia tem de servir para tirar lições, Sapo, Lisboa, 21 jun. 2017b. Disponível em https://24.sapo.pt/atualidade/artigos/pedrogao-grande-marcelo-defende-que-tragedia-tem-de-servir-para-tirar-licoes. Acesso em: 13 fev. 2019.

MCCRUDDEN, C.; PRECHAL, S. The Concepts of Equality and Non-Discrimination in Europe: a practical approach. Brussels: European Commission, 2009.

MOEDAS, Carlos. Carlos Moedas insta cientistas a gritarem pela ciência e a manifestarem-se. Diário de Notícias online, Lisboa, 22 abr. 2017. Disponível em: https://www. dn.pt/dinheiro/interior/carlos-moedas-insta-cientistas-a-gritarem-pela-ciencia-e-a-manifestarem-se-6238199.html. Acesso em: 20 fev. 2019.

MOREIRA, Vital. As universidades-fundação são tão públicas como as outras. In: MOREIRA, Vital Blogue Causa Nossa. Coimbra, 26. jan. 2017. Disponível em: https:/causa-nossa. blogspot.com/2017/01/as-universidades-fundacao-sao-tao.html. Acesso em: 30 jan. 2019.

NOVA SCHOOL OF BUSINESS \& ECONOMICS. [Faculdade de Economia da Universidade Nova de Lisboa]. Disponível em: https://www2.novasbe.unl.pt/pt/. Acesso em: Acesso em: 18 jan. 2019.

NOVOA, António. A modernização das universidades: Memórias contra o tempo. Rev. Port. de Educação, Braga, v. 31, n. Especial, p. 10-25, out. 2018. Disponível em http:// www.scielo.mec.pt/scielo.php?script $=$ sci_arttext\&pid $=$ S0871-91872018000200003\&lng $=$ pt\&nrm=iso. Acesso em: 26 jan. 2019.

OECD. Review of the Tertiary Education, Research and Innovation System in Portugal. Paris: OECD Publishing, 5 fev. 2018. Disponível em: https://www.santamariasaude.pt/sgc/ Assets/Plugins/CKEditor/kcfinder/Uploads/files/Review\%20of\%20TERI\%20in\%20Portugal\%206\%20February\%20DRAFT.pdf. Acesso em: 31 jan. 2019.

PARLAMENTO EUROPEU. Gabinete em Portugal. Eurobarómetro: maioria dos portugueses diz que pertença à UE é benéfica para o país. Lisboa, maio 2018. Disponível em http://www.europarl.europa.eu/portugal/pt/atualidades_e_destaques/destaques/eurobarometro2018.html. Acesso em: 20 fev. 2019.

PARTIDO SOCIALISTA. Programa eleitoral do Partido Socialista. Eleições legislativas 2015. Lisboa, out. 2015. Disponível em: https:/www.ps.pt/wp-content/uploads/2016/06/ programa_eleitoral-PS-legislativas2015.pdf. Acesso em: 21 fev. 2019

PINTO, Hugo Emanuel dos Reis Sales da Cruz. Transferência do conhecimento em Portugal: mudança e institucionalização das relações universidade-empresa. 2012. Tese (Doutorado) - Faculdade de Economia, UC, Coimbra, 2012. Disponível em http://hdl. handle.net/10316/21366. Acesso em: 24 jan. 2019.

PINTO, M. V. Vida e obra de um grande português. 2. ed. Lisboa: Âncora, 2017. 
PORTUGAL. Decreto-Lei n ${ }^{\circ}$ 448/79, de 13 de novembro, alterado por sucessivas leis e decretos-leis até à presente década. Estabelece o estatuto da carreira docente universitária. Diário da República, Lisboa, n. 262/1979, série I, n. 448/79, p. 2899-2917, 13 nov. 1979. Existe versão eletrónica. Lisboa: Diário da República Eletrónico. Disponível em: https://dre.pt/web/guest/pesquisa-avancada/-/asearch/367673/details/normal?types=SERI EI\&numero=448\%2F79\&tipo=\%22Decreto-Lei\%22. Acesso em 22 jan. 2019.

PORTUGAL. Lei $\mathrm{n}^{\circ}$ 62, de 10 de setembro de 2007. Estabelece o regime jurídico das instituições de ensino superior. Diário da República, Lisboa, n. 174, série I, n. 62, p. 63586389, 10 set. 2007. Existe versão eletrónica. Lisboa: Diário da República Eletrónico. Disponível em: https://dre.pt/web/guest/pesquisa/-/search/640339/details/maximized. Acesso em: 22 jan. 2019

PORTUGAL. Lei n. ${ }^{\circ}$ 49-A/2017, de 10 de julho. Cria a Comissão Técnica Independente para a análise célere e apuramento dos factos relativos aos incêndios que ocorreram em Pedrógão Grande, Castanheira de Pera, Ansião, Alvaiázere, Figueiró dos Vinhos, Arganil, Góis, Penela, Pampilhosa da Serra, Oleiros e Sertã entre 17 e 24 de junho de 2017. Diário da República, n. 131/2017, 1. ${ }^{\circ}$ suplemento, série I, n. 49-A/2017, p. 3530-(2) a 3530-(3), 10 jul. 2017. Existe versão eletrónica. Lisboa: Diário da República Eletrónico. Disponível em: https://dre.pt/application/conteudo/107669077. Acesso em: 23 de jan. 2019.

PORTUGAL. Lei n. 109-A/2017, de 14 de dezembro. Cria a Comissão Técnica Independente para a análise dos incêndios que ocorreram entre 14 e 16 de outubro de 2017 em Portugal Continental. Diário da República, n. 239/2017, 1. o suplemento, série I, n. 109-A/2017, p. 6616-(2) a 6616-(3), 14 dez. 2017. Existe versão eletrónica. Lisboa: Diário da República Eletrónico. Disponível em: https:/dre.pt/application/conteudo/114350962. Acesso em: 23 de jan. 2019.

RAVARA, Filipe Ravara. Portugal é um país grande em miniatura. Observador, Lisboa, 12 jul. 2017. Disponível em: http://observador.pt/2017/07/12/portugal-e-um-pais-grande-em-miniatura/. Acesso em: 12 jul. 2017.

REVISTA ENSINO SUPERIOR. São Paulo: Segmento, abr./maio/jun. 2017.

ROCHA, J. M. Moedas vai gerir 80 mil milhões como novo comissário da Investigação, Ciência e Inovação. Público, Lisboa, 10 set. 2014. Disponível em: https://www.publico. pt/2014/09/10/politica/noticia/carlos-moedas-sera-comissario-da-investigacao-inovacao-e-ciencia-1669190. Acesso em: 11 jan. 2019.

RODRIGUES, Maria João (coord.). Para uma Europa da Inovação e do Conhecimento. Emprego, reformas económicas e coesão social. Oeiras: Celta Editora, 2000.

SANTOS, Boaventura de Sousa. A universidade no século XXI: para uma reforma democrática e emancipatória da universidade. 2. ed. São Paulo: Cortez, 2005. 
SANTOS, Lucíola Licínio de CP. Entrevista com o prof. Antonio Nóvoa. Educ. Soc., v. 33, n. 119, p. 633-645, 2012. Disponível em: <ttp://www.scielo.br/scielo.php?script=sci arttext\&pid $=$ S0101-73302012000200016\&lng $=$ en\&nrm $=$ iso. http://dx.doi.org/10.1590/ S0101-73302012000200016. Acesso em: 26 jan. 2019.

SERRA, António Cruz. Uma nova carreira universitária. Público, Porto, 9 jun. 2018. Disponível em: https://www.publico.pt/2018/06/09/sociedade/opiniao/uma-nova-carreira-universitaria-1833434. Acesso em: 10 jun. 2018.

SILVA, A. C. Portugal e o futuro da União Europeia. Observador, Lisboa, 5 jun. 2018. Disponível em: https://observador.pt/especiais/portugal-e-o-futuro-da-uniao-europeia/. Acesso em: 22 jan. 2019.

SILVA, Jorge Moreira da. Globalização e política 4.0. Expresso, Lisboa, 8 ago. 2017. Disponível em: https:/expresso.pt/opiniao/2017-08-08-Globalizacao-e-politica-4.0\# gs.9mdg37. Acesso em: 10 out. 2018.

UNESCO. Fulfilling our collective responsibility: financing global public goods in education. Policy Paper 34. Paris: UNESCO, março 2018. Disponível em: https://unesdoc.unesco.org/ark:/48223/pf0000261530. Acesso em: 30 jan. 2019. 